\title{
The Effect of Bank Activity Restriction on Life Insurers' Efficiency: Evidence from European Markets
}

\author{
Rongrong Zhang \\ Department of Finance \& Quantitative Analysis \\ Georgia Southern University \\ P.O. Box 8151, Statesboro, GA 30460, USA \\ Tel: 1- 912-478-5799 E-mail: rzhang@georgiasouthern.edu
}

Received: January 10, 2012

Accepted: February17, 2012

Published: April 1, 2012

doi:10.5539/ijef.v4n4p55

URL: http://dx.doi.org/10.5539/ijef.v4n4p55

\begin{abstract}
This paper examines the relation between bank entry restrictions into insurance operations and life insurers' operating efficiency for a sample of 21 European countries over 1995-2003. Controlling for insurance market penetration, insurance risk retention, legal environment, and the economic development of the hosting country, we document that insurers operate more efficiently in markets with lower bank entry restrictions. Our results suggest that financial deregulation has positive spill-over effect, supporting the deregulation efforts in the global financial markets.
\end{abstract}

Keywords: Bank entry restrictions, Financial deregulation,Operating efficiency,Spill-over effect

JEL Classification: G2, G22, L11;

\section{Introduction}

Over the past twenty years, the global trend of financial deregulation and liberalization has had major impact on the operations of financial intermediaries such as banks and insurance companies. Banks are traditionally banned from engaging in non-banking services such as cross-selling insurance products, real estate management, and securities underwriting. Following deregulation, banks have greatly expanded their products and services and have been competing with brokers, investment banking firms, and insurance companies. Economics theory predicts competition within an industry enhances efficiency and prevents monopolistic behavior. There is scant research examining the cross-industry regulation effect. To the best of our knowledge, Carow (2001) is the only empirical research that addresses this topic in the financial industry. Building on theory of contestable markets (Baumol, 1982; Baumol, Panzar, and Willig, 1983), he hypothesizes that when banks are permitted by law to offer insurance services; the incumbent insurers are less likely to extract economic rents. Given that stock price is the discounted value of future cash flow, he predicts and documents a negative stock price reaction of insurance companies to the Supreme Court Rulings that allow banks to sell insurance products.

We extend Carow (2001) by testing the effect of bank regulation on insurers' efficiency using a cross country panel dataset. We use the bank activity index from World Bank banking supervision database as a proxy of the stringency of bank regulation. This index has three components measuring the restrictiveness of bank activities in the areas of (1) security underwriting; (2) insurance underwriting and selling, and (3) real estate investment. In this paper, we focus on area (2). We hypothesize that the degree of restriction on banks' insurance operations should have an adverse effect on insurance market competition which leads to less efficient operations of incumbent insurers. To test this hypothesis, we assemble the aggregate life insurers' operating performance data and banking market regulations information for a sample of 21 European countries over 1995-2003. We document higher operating efficiency in markets with less bank entry restrictions. Moreover, markets that raise bank entry restrictions experience a negative change in operating efficiency for life insurers. As a robustness check, we also explore the relation between the composite bank activity index (i.e. the restrictions in all three areas as mentioned above) and life insurers operating performance and find similar support for our view.

We contribute to literature in two ways. First, we provide additional empirical evidence in support of the theory of contestable markets. Previous studies in this area focus on banking market. Our research is the first using a large cross country insurance dataset. Second, we join a growing body of research that explores the benefits of bank-insurance structure by documenting efficiency gains to insurers by lowering entry restrictions to banks. Our 
findings support the policy initiatives aiming at lowering entry barriers to competition, thus to enhance efficiency and increase welfare of consumers. The spill-over effect documented in our study also has strong policy implications.

The rest of the paper is organized as follows. Section 2 discusses related research and hypotheses development; Section 3 describes our sample and variable constructions. Section 4 presents the empirical results. Section 5 concludes.

\section{Related Research and Hypothesis Development}

\subsection{Barriers for Entry to Banks and Insurance Market Competition}

Carow (2001) examines U.S.bank and insurance companies' stock price reactions to the Supreme Court rulings allowing banks to sell annuities and other insurance products and finds no significant changes in bank stock price and negative changes in insurance stock price. He focuses on the application of the theory of contestable markets in the insurance market. (Note 1) The main argument of the contestable market theory is that market can be contestable with a small group of incumbents with low entry barrier which creates "hit and run" opportunities. Banks are more adapt at offering products in the life and health insurance areas. As such, he shows that life and health insurance companies experienced most significant stock market losses following the Supreme Court rulings. Moreover,Carow (2001) shows that insurers wealth losses to these rulings are also related to the distribution methods, i.e., do they directly underwrite the insurance products, or use exclusive agents, independent agents, or brokers. Banks are most likely to use insurance brokers to underwrite these products. As such, insurers that use the broker distribution method are least affected by these court rulings.To our knowledge, Carow (2001) is the only empirical study that tests the impact of bank entry restrictions on insurers' performance.

With the passage of the Gramm-Leach-Bliley Act (1999),commercial banks, investment banks, securities firms, and insurance companies compete more aggressively against each other. Outside the U.S., Europe in particular, the practice of the universal banking encourages banks and the insurers both compete and cooperate. Bancassurance, i.e., marketing insurance products and services via bank networks becomes a very popular means of insurance distribution in several European markets such as France, Italy, Spain and Portugual (Legrand 2008). Empirical evidence suggests that merging bank and insurance business provides diversification benefits (Brown, Genetay \&M olyneux, 1996; Genetay \& Molyneux, 1998; Lown, Osler, Strahan \& Sufi, 2000; Nurullah \& Staikouras, 2008; Deng \& Elyasiani, 2008). Others document efficiency gains through the bancassurance structure (Fields, Fraser \& Kolari, 2007a, b). Studies also stock market reactions to the announcements of bank-insurance deals (Fields, Fraser \& Kolari, 2007a, b; Chen, Li, Moshirian \& Tan, 2007; Staikouras, 2009). We add to this strand of literature by exploring the efficiency gains in the insurance sector by lowering bank entry restrictions into insurance operations.

\subsection{Financial Deregulation in Europe}

The European financial market began its major deregulation efforts in the 1980s. Aiming at creating a common market for insurance, the European Union (EU) initiated a series of reforms including the first and second insurance directives, passed between 1973 and 1990 and the third generation insurance directives in 1994. The single passport proposal was adopted which permits insurance companies to offer EU wide services through a branch office upon approval by the local regulatory authority. Consumers are free to purchase insurance from any insurer based in the EU. These reforms lead to a major wave of mergers and acquisitions (M\&As) in the European markets. ((Note 2)Rees and Kessner (1999) examine the impact of a series of insurance directives aiming at harmonizing European insurance markets. They argue that these initiatives do not have the intended effect of stimulating competition across borders until there is a set of unified insurance laws across these markets. Prior research show mixed results on efficiency gains of consolidation in the financial services industry (Berger and Humphrey 1997). Berger (2003) conducts a research review on the efficiency effects of a single financial services market in Europe. He finds that the creation of a single market is unlikely to result in strong efficiency gains.Hussels, and Ward (2004) document an efficiency improvement in German life insurance industry post the adoption of the third Generation Insurance Directive. Cummings and Rubio-Misas (2001) examine the effects of deregulation and consolidation in Spanish insurance industry (1989 1998). As a result of major consolidations, the number of insurers declined significantly - small, inefficient, and financially under-performing firms were eliminated through liquidation. However, they also find that some large insurers still operate inefficiently.

Research reviewed above focus on the direct impact of financial regulation on either banks or insurance companies with the exception of Carow (2001), we extend his research by testing the spill-over effect of banking regulation on insurers using a large cross-country panel dataset. Our main hypothesis is formally stated as follows: 
Hypothesis I: restrictions on insurance operations by banks are inversely correlated with the efficiency of insurance companies.

Finding support for this view would be consistent with the theory of contestable markets. Moreover, we conjecture that insurance companies operate more efficiently following a decrease in banking regulations.

\section{Data and Variable Construction}

\subsection{Sample}

We assemble country-level life insurers' net premium, operation expenses, insurance market penetration, and risk retention ratio for a set of 21 European countries from 1995 to 2003 using Organization for Economic Cooperation and Development (OECD) bank profitability and insurance statistics database. (Note 3) Our measure of bank entry barrier is based on the bank activity index from the bank regulation and supervision surveys conducted by the World Bank. (Note 4) This survey contains a set of three bank activity regulatory variables measuring the extent to which banks are permitted to engage in underwriting and selling (1) securities; (2) insurance; (3) real estate; In this study, we focus bank activity regulations in area (2) and construct a variable Insure index which takes on integer values of $1 \sim 4$ indicating four levels of restrictiveness:

Insure $=1$ : Unrestricted - A full range of activities in the given category can be conducted directly in the bank.

Insure =2: Permitted - A full range of activities can be conducted, but all or some must be conducted in subsidiaries.

Insure $=3$ : Restricted - Less than a full range of activities can be conducted in the bank or subsidiaries.

Insure =4: Prohibited - The activity cannot be conducted in either the bank or subsidiaries.

The first World Bank regulation and supervision survey covers 117 countries between 1998 and 2000. (Note 5) It also updated this data in 2003 and 2008 respectively. Since our OECD insurance statistics database ends in 2003, the final sample is the intersection of these two data sources. Our final sample is unbalanced and consists of 169 country year observations from 1995 to 2003. The bank activity index thus contains the original World Bank survey and the 2003 update information. See Appendix A: Distribution of Insurer Index by Country for time period 1(1995-1999 survey I) and 2 (2000 - 2003 survey II).

\subsection{Regression Model}

We use the standard panel data estimation technique - a country fixed effect model specified as follows (Equation (1) \& (2)).(Note 6) See Appendix B for variable definitions.

$$
\begin{gathered}
\mathrm{OE}=\beta_{0}+\beta_{1} \text { Insure }+\beta_{2} \text { Penetration }+\beta_{3} \text { Retention }+\beta_{4} \text { Law }+\beta_{5} \log (\text { GDPpercap })+\varepsilon \\
\mathrm{OE}=\beta_{0}+\beta_{1} \text { Insure_H }+\beta_{2} \text { Penetration }+\beta_{3} \text { Retention }+\beta_{4} \text { Law }+\beta_{5} \log (\text { GDPpercap })+\varepsilon
\end{gathered}
$$

\subsubsection{Operating Expense Ratio (OE)}

Our measure of insurance market operating efficiency is the total operating expenses tonet premium ratio. High $\mathrm{OE}$ indicates low operating efficiency.

\subsubsection{Insure Index ( Insure, Insure_H)}

Our primary variable of interest is Insure Index as described in section 3.1. We also include a binary variable Insure_H (Equation 2) to account for possible non-linear effect of bank regulation. Insure_H is set to 1 if a country's insure index is above median and zero. A positive and significant coefficient $\left(\beta_{1}\right)$ supports our hypothesis.

\subsubsection{Market Penetration (Penetration)}

Market penetration is the ratio of a nation's gross insurance premiums to its gross domestic product (GDP) ratio. It captures the relative importance of the insurance industry in the domestic economy. We expect that insurers operate more efficiently in more developed insurance markets, i.e., a negative and significant coefficient $\left(\beta_{2}\right)$ is expected.

\subsubsection{Retention Ratio (Retention)}

Cummins and VanDerhei (1979) find a significant positive relationship between riskretention and expense ratio for the insurance companies. We use the ratio of net written premiums to total gross premiums to measure the proportion of retained business and expect a positive and significant coefficient $\left(\beta_{3}\right)$.

\subsubsection{Rule of Law (Law)}

La Porta et al. (1997 and 1998) first introduce the significant role of legal environments in the development of financial system and markets. Markets with strong shareholder and creditor protections should be able to allocate 
capital more efficiently. Hussels et al. (2005) discuss the importance of Legal systems in facilitating insurance demand and affect insurance company's insolvency. We include the rule of law factor (Kaufmann et al., 2008) and predict a negative coefficient on this variable. (Note 6)

\subsubsection{Economic Development (Log(GDP))}

We use the log of Gross Domestic Product (GDP) per capita to control for the effect of economic development. Prior insurance literature shows a non-linear relationship between economic development and insurance penetration - insurance penetration initially rises with the GDP. After the GDP reaches a certain level, penetration plateaus. There exists no direct evidence on the relationship between insurance efficiency and GDP per capita. We predict a negative coefficient on this variable, i.e. a positive relationship between economic development and insurers' operating efficiency.

\section{Empirical Results and Discussions}

Below we first present the time trend plot of European insurance market development, followed by some descriptive statistics, univariate tests, and regression results.

\subsection{Time Trend Plot}

Figure 1 presents the time trend plots of life insurance penetration by insurance index for the full sample. It appears both high and low insurance index countries experienced significant growth in insurance penetration up to year 2000. This is the period leading up to the establishment of the Economic and Monetary Union of Europe. Low insurance index markets have much higher insurance penetration compared to their counterparts.

To further explore the impact of Insure index on insurance market efficiency, we examine the subsets of markets that experienced either an increase or a decrease in bank activity restriction (insure index risers vs. decliners). Our full sample contains 169 country year observations. About 1/3 of the sample experienced no change in bank insurance regulations based on World Bank supervision and regulation survey $1 \& 2$ results. We have 112 country year observations that had either an increase or decrease in Insure index. From this subsample, we construct two groups - index risers, i.e. markets that raisedinsure index in survey 2 period; and indexdecliners, i.e. markets that lowered insure index in survey 2 period. Using these two groups, Figure 2 plots the time trend of their respective operating expense ratio. We identify a steady increase in operating expense ratio for index risers. By contrast, index decliners exhibit lower operating expense ratio post 1999. These results are consistent with our hypothesis that lowering bank entry barriers promote competition. As such, the incumbent insurers are forced to operate more efficiently.

\subsection{Univariate Results}

Table 1 presents the summary statistics. Table 2 presents the results of the test of mean differences of between high and low Insureindex markets. It shows that life insurers operate significantly less efficiently in high Insure index markets. These results are consistent with previous trend plots and provide some preliminary support for our hypothesis that operating efficiency of insurers is positively related to market openness to bank entry.

\subsection{Regression Results}

Table 3 presents country fixed effect regression results. The coefficient estimates with t-statistics have been adjusted for heteroskedasticity as in White (1980). As predicted, equations (1) and (2) both show a positive coefficient on insure index, however, it is only significant for the binary variable, suggesting that the effect of bank regulation on insurance performance may be non-linear. (Note 7) Similar to Cummins and VanDerhei (1979), we also find a significant and positive relationship between risk retention and expense. In addition, we find a significant and negative relationship between the rule of law and operating expense, consistent with Sylvester et al. (2005) showing law enforcement as a determinant of insurance market effectiveness. The negative coefficient on the log of GDP per capita supports the view that developed financial markets have more efficient insurance operations, ceteris paribus.

\subsection{Robustness Check}

As a robustness check, we replace the insurer index with the overall banking activity index $(O V E R 3 A R)$. This index measures restiveness on banking operations in areas of (1) security underwriting; (2) insurance underwriting and selling, and (3) real estate investment. High OVER3AR indicates banks have less flexibility in diversifying and competing in the non-traditional banking areas. Our hypothesis is supported using this variable.

\section{Summary and Conclusion}

This paper examinesthe spill-over effect of regulation on banks' insurance underwriting and selling activities on insurers' performance. Using a sample of 169 country year panel data set from 21 European nations, we show that 
markets with higher levels of restrictions on banks' insurance activities have lower insurance operating efficiency. Second, markets that raised restrictions on banking activities experience significant drop in operating efficiency. Together, these findings support the contestable markets theory - low entry barriers encourage hit and run new entrants to compete with incumbents, as a result, incumbents are unable to earn economic rents in the long run. Our finding has important policy implications - regulators need to consider the "spill-over" effect when design and implement new rules and regulations.

Our study has a few limitations. Due to data limitations, our tests are conducted on a country wide basis rather than at individual firm level. Even though we document statisticalsignificance for our key variables, these results do not imply causality.Our sample period overlaps with the major deregulation insurance initiatives in the European markets. As discussed in section 2, prior research has examined the topic of consolidation and efficiency in the financial services industries and document mixed results. We do not directly control for the effect of consolidation due to data unavailability given that the major regulatory developments affect all of our sample markets.

\section{References}

Baumol, William J. (1982). Contestable Markets: An Uprising in the Theory of Industry Structure.American Economic Review, American Economic Association, vol. 72(1), 1-15, March.

Baumol, William J., Panzar, John C., \& Willig, Robert D. (1983). Contestable Markets: An Uprising in the Theory of Industry Structure: Reply. American Economic Review, American Economic Association, 73(3), 491-96, June.

Barth, J. R., G. Caprio Jr., \& R. Levine. (2001). The Regulation and Supervision of Bank Around the World: A New Database, in Robert E. Litan and Richard Herring, Editors, Integrating Emerging Market Countries into the Global Financial System, Brookings-Wharton Papers on Financial Services, Brookings Institution Press. http://dx.doi.org/10.1353/pfs.2001.0003

Beck, T., A. Demirgüç-Kunt, \& R. Levine. (2001a). A New DataBase on Financial Development and Structure.World Bank Economic Review, 14(3), 597-605.

Berger, Allen N., \& David B. Humphrey. (1997). Efficiency of Financial Institutions: International Survey and Directions for Future Research. European Journal of Operational Research, 98, 175-213.

Brown, M., N. Genetay, \& P. Molyneux. (1996). Risk Effects of Bank Diversification into Lifeassurance: UK evidence. Institute of European Finance, University of Wales, Bangor.

Carow, K.A. (2001). The Wealth Effects of Allowing Bank Entry into the Insurance Industry. Journal of Risk and Insurance, 68:129-150. http://dx.doi.org/10.2307/2678134

Chen, Z., \& J. Tan. (2011). Does BancassuranceAdd Value to Banks? Evidence from mergers and acquisitions between European banks and insurance companies. Research in International Business and Finance, 25, Issue 1, 104-112.http://dx.doi.org/10.1016/j.ribaf.2010.08.002

Cummins, J. D., \& Maria Rubio-Misas. (2001). Deregulation, Consolidation, and Efficiency: Evidence From the Spanish Insurance Industry, Center for Financial Institutions Working Papers 02-01, Wharton School Center for Financial Institutions, University of Pennsylvania.

Cummins, J. D., \& Jack VanDerhei. (1979). A Note on the Relative Efficiency of Property-Liability Insurance Distribution Systems. Bell Journal of Economics, The RAND Corporation, 10(2), 709-719. http://dx.doi.org/10.2307/3003362

Deng, S., \& E. Elyasiani. (2008). Geographic diversification, bank holding company valueand risk. Journal of Money, Credit and Banking, Forthcoming, 40, Issue 6, 1217-1238. http://dx.doi.org/10.1111/j.1538-4616.2008.00154.x

Fields, L. P., D.R. Fraser, \& J.W. Kolari. (2007a). Bidder returns in Bancassurance Mergers: Is there evidence of synergy? Journal of Banking and Finance, 31:3646-3662.http://dx.doi.org/10.1016/j.jbankfin.2007.01.014

Fields, L.P., D.R. Fraser, \& J.W. Kolari. (2007b). Isbancassurance a viable model for financial firms? Journal of Risk and Insurance, 74:777-794.

Genetay, N., \& P. Molyneux. (1998). Bancassurance. London: Macmillan.

Hussels, S., D. Ward, \& R. Zurbruegg.(2005). Stimulating the Demand for Insurance. Risk Management and Insurance Review, 8(2): 257-278. http://dx.doi.org/10.1111/j.1540-6296.2005.00059.x

Kaufmann, Daniel, AartKraay, \& Massimo Mastruzzi. (2009). Governance Matters VII: Aggregate and Individual Governance Indicators 1996-2007, Cambridge University Press. http://dx.doi.org/10.1017/CBO9780511635519.007 
La Porta, R., F. Lopez-de-Silanes, A. Shleifer, \& R. Vishny. (1997). Legal Determinants of External Finance. Journal of Finance, 52(3): 1131-1150.

La Porta, R., F. Lopez-de-Silanes, A. Shleifer, \& R. Vishny. (1998). Law and Finance. Journal of Political Economy, 106: $1133-1155$.

Legrand, C. (2008). European Bancassurance Benchmark, Milliman report. http://it.milliman.com/Pubblicazioni/pdfs/european-bancassurance-benchmark-08-01-08. pdf .

Lown, C.S., C.L. Osler, P.E. Strahan, \& A. Sufi. (2000). The changing landscape of the financial services industry: What lies ahead? Federal Reserve Bank of New York Economic Policy Review, 39-55.

Nurullah, M., \& S. K. Staikouras. (2008). The separation of banking from insurance: Evidence from Europe. Multinational Finance Journal, 12,157-184.

Rees, R., \& Kessner, E. (1999). Regulation and efficiency in European insurance markets. Economic Policy, 14: 363-398. http://dx.doi.org/10.1111/1468-0327.00053

Staikouras S.K. (2009). An event study analysis of international ventures between banks and insurance firms.

Journal of International Financial Markets, Institutions and Money, 19, 675-691. http://dx.doi.org/10.1016/j.intfin.2008.11.003

\section{Notes}

Note 1 . The theory of contestable marketsholds that markets can be competitiveeven in the presence of a small number of firms as long as the entry barrier is low. In that case, incumbents cannot earn economic rents in the face of "hit and run" entrants.

Note 2. Cummins and Weiss (2004) document a total of 2,595 M\&As involving European insurers between 1990 and 2002.

Note 3. OECD members include countries outside Europe continent. We restrict our analysis to EU countries considering these markets are more homogeneous to each other than those outside Europe. For example, Australia, Japan, and Korea are OECD members, but they are not included in our analyses.

Note 4. See Barth, Caprio, and Levine (2001) and Beck, Demirgüç-Kunt, and Levine (2001) for more discussions on this data.

Note 5. Most data was collected as of 1999.

The Hausman test statistics indicates fixed country effect is more appropriate than random effect mode.

Note 6. Kaufmann et al. (2008) developed a series of six governance indicators that examine the effect of legal and government factors on a nation's financial market development. Their Worldwide Governance Indicators include: (1) voice and accountability, (2) political stability, (3) absence of violence, (4) government effectiveness, (5) rule of law and (6) regulatory quality. Sylvester et al (2005) noted law enforcement as a factor leading to insurance market effectiveness. Hence, we chose the rule of law factor rather than the other governance factors to be included in our efficiency model. The correlation analysis also indicates these six factors are highly correlated.

Note 7. We run regression with a quadratic term of insure index and find a positive coefficient for the quadratic term. This suggests that the adverse impact of restriction on bank operations on insurers performance starts after the insure index reaches a certain level. 